Vol. 1 No. 2 September 2021, p-2797-5592 | e-2797-5606

\title{
UPAYA MENINGKATAN KOPETENSI GURU KELAS RENDAH DALAM MENYUSUN ADMINISTRASI PEMBELAJARAN MELALUI SUPERVISI AKADEMIK PADA MASA PANDEMI COVID-19 DI SDN KEDUNGDORO V/310 SURABAYA
}

\author{
SUMARTINI
}

SDN Kedungdoro V/310 Surabaya

e-mail: sdn.kedungdoro5@gmail.com

\begin{abstract}
ABSTRAK
Penelitian yang dilakukan ini merupakan penelitian tindakan sekolah (PTS) yang mengangkat tentang bagaimana guru dapat menggunakan administrasi pembelajaran yang ada dalam proses pembelajaran di kelas dengan maksud dapat meningkat kualitas pembelajaran yang dilakukan di kelas dan evaluasinya dilakukan melalui kegiatan supervise kepala sekolah di kelas saat pembelajaran. Kegiatan penelitian tindakan sekolah ini dilakukan di SDN Kedungdoro V/310 selama 3 bulan yaitu mulai bulan Juli sampai dengan September 2021 dengan melalui tahapantahapan siklus. Tujuan dari penelitian tindakan sekolah (PTS) ini adalah untuk mengetahui sejauh mana supervisi yang dilakukan oleh kepala sekolah yang diikuti dengan pemberian pembinaan/perlakuan terhadap guru-guru sasaran dapat meningkatkan Kopetensi guru kelas rendah tersebut dalam menyusun administrasi pembelajaran. Dalam penelitian tindakan sekolah (PTS) ini dilakukan dalam 2 siklus, dari hasil tindakan yang dilakukan terbukti dapat meningkatkan Kopetensi guru kelas rendah dengan mencapai standar ideal. Pada siklus I peningkatan Kopetensi guru kelas rendah dalam menyusun administrasi pembelajaran mencapai sekitar 33,33 \% ,pada siklus II dapat meningkat menjadi $100 \%$. Skor rata-rata yang diperoleh setelah dilakukan supervisi kelas pada siklus I sebesar 71,33 dan meningkat pada siklus II menjadi 83,33, berarti ada peningkatan sebesar 12 dan tingkat ketuntasan secara kelompok/klasikal pada siklus I mencapai 33,33\% dan pada siklus II meningkat menjadi 100 $\%$. Hasil penelitian tindakan sekolah ini menunjukkan bahwa pembinaan kepala sekolah dapat meningkatkan Kopetensi guru kelas rendah dalam menyusun administrasi pembelajaran.
\end{abstract}

Kata Kunci : Kopetensi guru kelas rendah, Supervisi Akademik

\begin{abstract}
This research is a school action research (PTS) which raises about how teachers can use the existing learning administration in the learning process in the classroom with the intention of increasing the quality of learning carried out in the classroom and the evaluation is carried out through the supervision of the principal in the classroom during learning. This school action research activity was carried out at SDN Kedungdoro V/310 for 3 months, starting from July to September 2021 by going through cycle stages. The purpose of this school action research (PTS) is to determine the extent to which the supervision carried out by the principal followed by the provision of guidance/treatment to the target teachers can increase the competence of the low-grade teachers in preparing learning administration. In this school action research (PTS), it was carried out in 2 cycles, from the results of the actions taken it was proven to be able to increase the competence of low grade teachers by achieving ideal standards. In the first cycle, the increase in the competence of low-grade teachers in preparing learning administration reached about $33.33 \%$, in the second cycle it could increase to $100 \%$. The average score obtained after class supervision in the first cycle was 71.33 and increased in the second cycle to 83.33, meaning that there was an increase of 12 and the level of completeness as a group/classical in the first cycle reached $33.33 \%$ and in the first cycle it was $33.33 \%$. II increased to $100 \%$. The results of this school action research indicate that the coaching of the principal can improve the competence of low-grade teachers in preparing learning administration.
\end{abstract}

Keywords: Low grade teacher competence, Academic Supervision 


\section{PENDAHULUAN}

Kemampuan menurut Kusnandar (2008:52) adalah suatu yang dimiliki oleh seseoraang untuk melakukan tugas daan pekerjaan yang dibebankan kepadanya. Menurut Broker dan Stone (dalam Cece Wijaya, 1991:7) memberikan pengertian Kompetensi Guru Kelas adalah sebagai gambaran hakikat kualitatif dari perilaku guru atau tenaga kependidikan yang tampak sangat berarti. Jadi berdasarkan pengertian tersebut penulis dapat mengambil kesimpulan bahwa Kompetensi Guru Kelas adalah potensi yang dimiliki guru untuk melakukan suatu aktivitas. Kompetensi guru yang mampu mengubah mindsetnya terlihat pada tahap-tahap pembelajaran (Usman, 2018).

Menurut Ross L (1980:2) Supervisi adalah pelayanan kepada guru-guru yang bertujuan menghasilkan perbaikan pengajaran, pembelajaran dan kurikulum. Ross L memandang supervisi sebagai pelayanan kepada guru-guru yang bertujuan menghasilkan perbaikan. Menurut Imron yang dikutip oleh Abrani Syauqi dkk (2016:342) menjelaskan akademik berasal dari bahasa Inggris academy berasal dari bahasa latin academia mempunyai banyak arti yang salah satunya yaitu suatu masyarakat atau kumpulan orang-orang terpelajar, kata akademik juga mempunyai berbagai macam makna antara lain yaitu bersifat teoritis bukan praktis, kajian yang lebar dan mendalam bukan kajian teknis dan konversial dan sangat ilmiah.

Menurut Piet A, Suhertian (2010:19) tujuan supervisi akademik adalah memberikan layanan dan bantuan untuk mengembangkan situasi belajar mengajar yang dilakukan guru dikelas. Melalui supervisi akademik diharapkan kualitas akademik yang dilakukan oleh guru semakin meningkat. Pengembangan kemampuan dalam konteks ini janganlah ditafsirkan secara sempit, semata-mata ditekankan pada peningkatan pengetahuan dan keterampilan mengajar guru, melainkan juga pada peningkatan komitmen (commitmen) atau kemauan (willingness) atau motivasi (motivation) guru, sebab dengan meningkatkan kemampuan dan motivasi kerja guru, kualitas pembelajaran akan meningkat.

Program-program supervise hendaknya memberikan rangsangan terhadap terjadinya perubahan dalam kegiatan pembelajaran. Perubahan-perubahan ini dapat dilakukan melalui kegiatan-kegiatan dalam pembinaan, arahan dan pengembangan kurikulum dengan mengikuti pelatihan-pelatihan. Menurut E Mulyana (2010:113) Kepala sekolah sebagai supervisor, dapat dilaksanakan secara efektif antara lain; kunjungan kelas, diskusi kelompok, pembinaan individual, dan simulasi pembelajaran.

Menurut Suharsimi Arikunto (2004:33) sasaran supervisi ada tiga macam (1) supervisi akademik yang menitikberatkan pengamatan supervisor pada masalah-masalah akademik, yaitu hal-hal yang berlangsung dalam lingkungan kegiatan pembelajaran pada waktu peserta didik sedang dalam proses mempelajari sesuatu; (2) supervisi administrasi yang menitikberatkan pengamatan supervisor pada aspek-aspek administrasi yang berfungsi sebagai pendukung dan pelancar terlaksananya; dan (3) supervisi lembaga yang menebar dan menyebarkan obyek pengamatan supervisor pada aspek-aspek yang berada di seantero sekolah.

Berdasarkan peraturan pemerintah nomor 74 tahun 2008, pasal 52 ayat (1) yang mencakup kegiatan pokok yaitu merencanakan pembelajaran, menilai hasil pembelajaran, membimbing dan melatih peserta didik, serta melaksanakan tugas tambahan yang melekat pada pelaksanaan tugas pokok, yaitu sebagai administrastor akan tetapi kenyataannya tidak semua guru mengajar melakukan itu, masih ada guru mengajar tanpa menyusun kelengkapan administrasi mengajar, sehingga dapat kita bayangkan bagaimana hasil pembelajaran yang dicapai, sudah barang tentu tujuan pembelajaran yang telah diamanatkan oleh undang-undang tidak akan tercapai tanpa direncanakan. Berdasarkan hasil pemantauan kepala sekolah, masih banyak teman-teman guru yang belum mampu melaksanakan tugas pokoknya dengan baik, karena kurang kemampuannya dalam menyusun administrasi pembelajaran.

Permasalahan yang sering dihadapi guru di SDN Kedungdoro V/310 tidak lepas dari beberapa masalah diatas seperti guru yang kurang mampu menyusun RPP, tidak sesuai antara RPP dengan apa yang dijelaskan dalam proses pembelajaran, guru belum mampu menggunakan 
strategi pembelajaran yang bervariasi, kemampuan dalam pembelajaran masih rendah. Di SDN Kedungdoro V/310 pada awal pelaksanaan supervisi ada beberapa guru masih perlu bimbingan dalam pembuatan RPP termasuk pada komponen-komponennya yaitu merumuskan tujuan, pembelajaran, bahan/ materi ajar, strategi pembelajaran dan penilaian.

Berangkat dari permasalahan tersebut, diperlukan pembinaan terhadap guru yang teridentifikasi masih memiliki masalah baik pada proses pembuatan RPP maupun dalam proses pembelajaran. Salah satu yang dilakukan paling penting adalah melalui supervisi akademik oleh Kepala Sekolah. Supervisi akademik yang dimaksud disini tidak hanya berhenti pada pencermatan dokumen RPP dan pemantauan kegiatan pembelajaran, tetapi juga dilanjutkan dengan menindaklanjuti setiap temuan, maka dalam hal ini perlu diutarakan bagaimana bimbingan terhadap guru tersebut, maka setelah itu dilakukan bimbingan untuk bisa menyusun RPP dengan baik dan sempurna sesuai dengan tujuan pendidikan dan standar proses. Maka dalam hal ini perlu dipaparkan bagaimana caranya untuk melakukan supervisi yaitu: (1). Secara individual, pelaksanaan supervisi perseorangan terhadap guru. (2). Secara kelompok, pelaksanaan supervisi ditujuakan pada dua orang atau lebih dengan masalah yang sama.

Supervisi individual dilakukan dengan cara kunjungan kelas, observasi kelas, pemantauan individual, kunjungan antar kelas, dan menilai diri sendiri. Cara pelaksanaan kunjungan kelas antara lain: dengan atau tanpa pemberitahuan terlebihdahulu, permintaan guru yang bersangkutan, telah memiliki instrumen atau catatan tujuan kunjungan kelas harus jelas. Tahapan-tahapan kunjungan kelas, persiapan, merencanakan waktu, sasaran, dan cara mengobservasi, pengamatan selama kunjungan, memberikan hasil dan tindak lanjut.

\section{METODE PENELITIAN}

Subjek yang akan di supervisi adalah guru Kelas Rendah di SDN Kedungdoro V/310, adapun sasaran utama dilakukannya supervisi akademik SDN Kedungdoro V/310 adalah untuk menguji kemampuan-kompetensi guru kelas dalam merencanakan kegiatan pembelajaran, melaksanakan kegiatan pembelajaran, menilai hasil pembelajaran, memanfaatkan hasil penilaian untuk peningkatan layanan pembelajaran, menciptakan lingkungan belajar yang menyenangkan, memanfaatkan sumber belajar yang tersedia, dan mengembangkan interaksi pembelajaran (strategi, metode, teknik) yang tepat.

Prosedur penelitian merupakan suatu bentuk gambaran untuk mempermudah langkahlangkah pemecahan masalah atau pengujian hipotesis. Pada penelitian tindakan sekolah ini, memiliki cirri utama yaitu terdapat siklus-siklus yang tiap siklusnya memiliki tahapan-tahapan yaitu : a) perencanaan tindakan (planning), b) tindakan (acting), c) pengamatan (observasing), d) refleksi (reflecting). Prosedur penelitian yang dilakukan mengikuti bagan yang dikemukakan oleh (Suharsimi Arikunto, 2008:16). Model bagan dan penjelasan untuk masing-masing tahap adalah sebagai berikut:

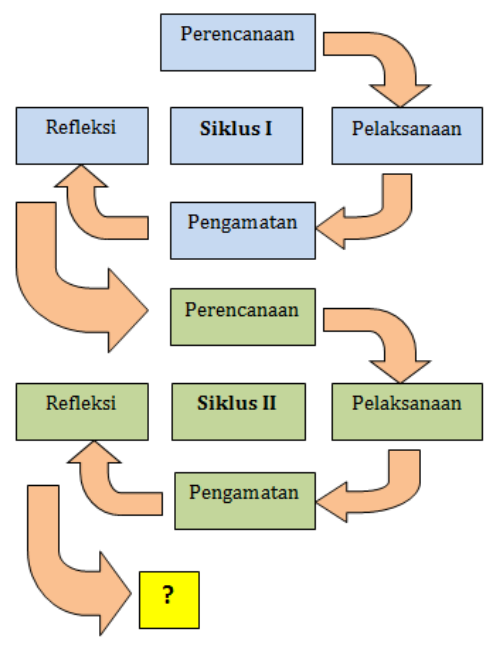




\section{HASIL DAN PEMBAHASAN}

\section{Hasil}

Siklus I

Pelaksanaan kegiatan pembinaan untuk siklus I dilaksanakan tanggal 12 s.d 31 Juli 2021 di SDN Kedungdoro V/310 Kecamatan Tegalsari Surabaya. dengan jumlah guru 3 Orang. Dalam hal ini peneliti bertindak sebagai Kepala Sekolah. Adapun proses pembinaan mengacu pada rencana pelajaran yang telah dipersiapkan. Pengamatan (observasi) dilaksanakan bersamaan dengan pelaksaaan belajar mengajar. Pada akhir proses pembinaan, guru dan kepala sekolah menyepakati waktu pelaksanaan supervisi di kelas dengan tujuan untuk mengetahui tingkat Kompetensi Guru Kelas Rendah dalam proses belajar mengajar yang telah dilakukan. Adapun data hasil penelitian pada siklus I. adalah seperti pada tabel berikut :

Tabel 1. Tabel hasil Supervisi Akademik Pada Siklus I

\begin{tabular}{|c|c|c|c|c|}
\hline \multirow[b]{2}{*}{$\begin{array}{l}\mathbf{N} \\
\mathbf{0}\end{array}$} & \multirow[b]{2}{*}{ Nama Responden } & \multirow[b]{2}{*}{ Skor } & \multicolumn{2}{|c|}{ Keterangan } \\
\hline & & & Tuntas & $\begin{array}{l}\text { Tidak } \\
\text { Tuntas }\end{array}$ \\
\hline 1 & $\mathrm{X} 1$ & 78 & $\sqrt{ }$ & \\
\hline 2 & $\mathrm{X} 2$ & 67 & & $\sqrt{ }$ \\
\hline 3 & $\mathrm{X} 3$ & 79 & $\sqrt{ }$ & \\
\hline \multicolumn{2}{|c|}{ Jumlah Nilai } & 224 & - & - \\
\hline \multicolumn{2}{|c|}{ Nilai rata-rata } & 74,66 & - & - \\
\hline \multicolumn{2}{|c|}{$\begin{array}{l}\text { \% Jumlah Guru Yang Mencapai nilai } \\
\text { Supervisi Akademik minimal } 75\end{array}$} & \multicolumn{3}{|c|}{$66,67 \%(=2$ guru $)$} \\
\hline
\end{tabular}

Dari tabel di atas dapat dijelaskan bahwa dengan menerapkan supervisi akademik kepala sekolah diperoleh nilai rata-rata Kopetensi Guru Kelas Rendah adalah 74,66 dan ada 2 orang guru dari 3 orang sudah meningkat mutunya dalam proses belajar mengajar. Hasil tersebut menunjukkan bahwa pada siklus pertama secara kelompok guru(sekolah) belum meningkat mutunya, karena guru yang memperoleh nilai $\geq 75$ hanya sebesar $66,67 \%$ artinya lebih kecil dari persentase ketuntasan yang dikehendaki yaitu sebesar $\geq 85 \%$. Hal ini disebabkan karena guru masih merasa baru dan belum mengerti apa yang dimaksudkan dan dijelaskan oleh Kepala Sekolah dalam pembinaan kaitan dengan penerapan model pembelajaranoleh guru-guru tersebut masih agak mengalami kesulitan dalam penyampaian materi pembelajaran.

\section{Siklus II}

Pelaksanaan kegiatan pembinaan untuk siklus II dilaksanakan pada tanggal 16 s.d 31 Agustus 2021 di SDN Kedungdoro V/310 Kecamatan Tegalsari Surabaya tahun pelajaran 2021/2022 Dalam hal ini peneliti bertindak sebagai Kepala Sekolah. Adapun proses pembinaan mengacu pada rencana pembinaan dengan memperhatikan revisi pada siklus I, sehingga kesalahan atau kekurangan pada siklus I tidak terulang lagi pada siklus II. Pengamatan (observasi) dilaksanakan bersamaan dengan pelaksanaan belajar mengajar.

Pada akhir proses pembinaan, guru dan kepala sekolah menyepakati waktu supervisi di kelas dengan tujuan untuk mengetahui peningkatan Kopetensi Guru Kelas Rendahdalam proses pembinaan yang telah dilakukan. Instrumen yang digunakan adalah tes formatif II. Adapun data hasil penelitian pada siklus II adalah sebagai berikut : 
Vol. 1 No. 2 September 2021, p-2797-5592 | e-2797-5606

\section{Tabel 2. Tabel Distribusi Skor Hasil Supervisi Akademik Pada Siklus II}

\begin{tabular}{|l|l|c|c|c|}
\hline \multirow{2}{*}{$\begin{array}{l}\text { N } \\
\text { o }\end{array}$} & Nama Responden & \multirow{3}{*}{ Skor } & Keterangan \\
\cline { 3 - 5 } & & 85 & $\sqrt{ }$ & \\
\hline 1 & $\mathrm{X} 1$ & 83 & $\sqrt{ }$ & \\
\hline 2 & $\mathrm{X} 2$ & 88 & $\sqrt{ }$ & \\
\hline 3 & $\mathrm{X} 3$ & 256 & - & - \\
\hline Jumlah Nilai & 85,33 & - & - \\
\hline Nilai rata-rata & $100 \%(=3$ guru $)$ \\
\hline $\begin{array}{l}\text { \% Jumlah Guru Yang Mencapai nilai } \\
\text { Supervisi Akademik minimal 75 }\end{array}$ & - & \\
\hline
\end{tabular}

Dari tabel di atas diperoleh nilai rata-rata peningkatan Kopetensi Guru Kelas Rendahadalah 85,33 dan ketuntasan pembinaan mencapai $100 \%$ atau semua guru kelas yang dijadikan sasaran penelitian sudah meningkat mutunya dalam proses belajar mengajar. Hasil ini menunjukkan bahwa pada siklus II ini ketuntasan belajar 100\%.

Dari data-data yang telah diperoleh dapat duraikan sebagai berikut (1) Selama proses pembinaan Kepala Sekolah telah melaksanakan semua pembinaan dengan baik. Meskipun ada beberapa aspek yang belum sempurna, tetapi persentase pelaksanaannya untuk masing-masing aspek cukup besar. (2) Berdasarkan data hasil pengamatan diketahui bahwa guru aktif selama proses belajar berlangsung. (3) Kekurangan pada siklus-siklus sebelumnya sudah mengalami perbaikan dan peningkatan sehingga menjadi lebih baik. (4) Hasil pembinaan guru oleh kepala sekolah melalui supervisi akademik pada siklus II mencapai ketuntasan $100 \%$

Pada siklus II guru telah menerapkan model pembelajaran melalui pembinaan kepala sekolah dengan baik dan dilihat dari aktivitas guru serta hasil pembinaan guru pelaksanaan proses pembinaan sudah berjalan dengan baik. Maka tidak diperlukan revisi terlalu banyak, tetapi yang perlu diperhatikan untuk tindakan selanjutnya adalah memaksimalkan dan mempertahankan apa yang telah ada dengan tujuan agar pada pelaksanaan proses belajar mengajar selanjutnya pembinaan yang dilakukan Kepala Sekolah dapat meningkatkan Kopetensi Guru Kelas Rendahdalam proses belajar mengajar dalam menerapkan model pembelajaran sehingga tujuan pembelajaran dapat tercapai.

\section{Pembahasan}

1. Ketuntasan hasil pembinaan kepada guru

Berdasarkan hasil penelitian ini menunjukkan bahwa penerapan model pembelajaran melalui binaan Kepala Sekolah memiliki dampak positif dalam meningkatkan Kopetensi Guru Kelas Tinggi. Hal ini dapat dilihat dari semakin mantapnya pemahaman guru dari pembinaan yang diberikan oleh kepala sekolah (rata-rata hasil Kopetensi Guru Kelas Rendah meningkat dari siklus I, dan II) yaitu masing-masing 74,66 dan ; 85,33. Pada siklus II ketuntasan pembinaan guru secara kelompok telah tercapai.

\section{Kemampuan Kepala Sekolah dalam melakukan pembinaan.}

Berdasarkan analisis data, diperoleh aktivitas guru dalam pembinaan yang dilakukan Kepala Sekolah dalam menerapkan model pembelajaran dalam setiap siklus mengalami peningkatan. Hal ini berdampak positif terhadap peningkatan Kopetensi Guru Kelas Rendahyaitu dapat ditunjukkan dengan meningkatnya nilai rata-rata yang dicapai guru pada setiap siklus yang terus mengalami peningkatan.

\section{Aktivitas kepala sekolah dan guru dalam pembinaan}

Berdasarkan analisis data, diperoleh aktivitas guru dan Kepala Sekolah dalam proses pembinaan melalui penerapan model pembelajaran yang paling dominan adalah bekerja dengan 
Vol. 1 No. 2 September 2021, p-2797-5592 | e-2797-5606

menggunakan alat/media, mendengarkan/memperhatikan penjelasan Kepala Sekolah, dan diskusi antar guru antara guru dan Kepala Sekolah. Jadi dapat dikatakan bahwa aktivitas guru dapat dikategorikan aktif. Sedangkan untuk aktivitas Kepala Sekolah selama pembinaan telah melaksanakan langkah-langkah pembinaan pelatihan berkelanjutan dengan baik. Hal ini terlihat dari aktivitas Kepala Sekolah yang muncul di antaranya aktivitas membimbing dan mengamati guru dalam mengerjakan kegiatan pembelajaran, menjelaskan, memberi umpan balik/evaluasi/tanya jawab di mana prosentase untuk aktivitas di atas cukup besar.

Berdasarkan hasil penelitian di atas, maka hasil pembinaan Kepala Sekolah hasilnya sangat baik. Hal itu tampak pada pertemuan pertama dari 3 Orang guru yang hadir pada saat penelitian ini dilakukan ketuntasan pencapaian Kemampuan ideal dari siklus I dan siklus II masing-masing yaitu $66,67 \%$ meningkat menjadi $100 \%$

Dari analisis data di atas bahwa pembinaan dalam meningkatkan Kopetensi Guru Kelas Rendahdalam menerapkan model pembelajaran melalui pembinaan Kepala Sekolah, yang berarti proses kegiatan belajar mengajar lebih berhasil dan dapat meningkatkan mutunya khususnya di SDN Kedungdoro V/310 Kecamatan Tegalsari Surabaya, oleh karena itu diharapkan kepada para guru SDN Kedungdoro V/310 dapat meningkatkan mutunya dalam melaksanakan pembelajaran di kelas.

Berdasarkan manajemen berbasis sekolah (MBS) dikatakan tuntas apabila guru telah mencapai nilai KKM sebesar 75 mencapai $\geq 83,33 \%$. Sedangkan pada penilitian ini, pencapaian nilai $\geq 75$ pada (siklus II) mencapai melebihi target yang ditetapkan dalam MBS yaitu mencapai $100 \%$.

Penelitian tentang penerapan supervisi akademik dilakukan oleh (Tama, 2009) di SMP Negeri 1 Kuta Utara dengan populasi dan sampel 80 orang (penelitian sensus) ditemukan bahwa supervisi akademik mempunyai pengaruh yang lebih baik dibandingkan sebelum diberikan supervisi akademik terhadap kompetensi pedagogik guru. Salah satu upaya peningkatan profesional mutu kinerja guru adalah melalui supervisi akademik. Pelaksanaan supervisi akademik perlu dilakukan secara sistematis oleh kepala sekolah dan pengawas yang bertujuan memberikan pembinaan kepada guru-guru agar dapat melaksanakan tugasnya secara efektif dan efisien

Hendriyathi, (2012) juga telah menulis artikel tentang Pembinaan Profesional Melalui Supervisi Akademik Sebagai Upaya Peningkatan Mutu Kinerja Guru Pada Sekolah Dasar Santo Yoseph 1 Denpasar. Kaitan artikel tersebut dengan penelitian ini adalah sama-sama berpendapat bahwa supervisi akademik merupakan salah satu sumber acuan dalam pengembangan profesional tenaga kependidikan (khususnya guru), melalui efektifitas dimensi kompetensi supervisi akademik oleh kepala sekolah dan pengawas sekolah, dengan memaksimalkan kegiatan supervisi akademik diharapkan tenaga guru dapat meningkatkan pengetahuan dan ketrampilan dalam proses pembelajaran. Semakin sering dilaksanakan supervisi akademik oleh kepala sekolah dan pengawas sekolah terhadap guru dapat meningkatkan secara signifikan kualitas kinerja guru dalam proses pembelajaran.

\section{KESIMPULAN}

Dari hasil kegiatan pembinaan yang telah dilakukan selama dua siklus, dan berdasarkan seluruh pembahasan serta analisis yang telah dilakukan dapat disimpulkan sebagai berikut : Penerapan Supervisi Administrasi dapat meningkatkan Kopetensi Guru Kelas Rendahdalam memanfaatkan media pembelajaran di SDN Kedungdoro V/310 Kecamatan Tegalsari Surabaya tahun pelajaran 2021/2022

\section{DAFTAR PUSTAKA}

Abrani Syauqi dkk. (2016). Supervisi Pendidikan Islam. Yogyakarta: Aswaja Arikunto Suharsimi. 2007. Penelitian Tindakan Kelas. Jakarta: PT.Bumi Aksara.

Hendriyathi. (2012). Pembinaan Profesional Melalui Supervisi Akademik Sebagai Upaya Peningkatan Mutu Kinerja Guru Pada SD Santo Yoseph I Denpasar. 
Vol. 1 No. 2 September 2021, p-2797-5592 | e-2797-5606

Mulyana, Deddy. (2010). Metodologi Penelitian Kualitatif. Bandung: PT. Remaja Rosdakarya

Sahertian, Piet A. (2010). Konsep Dasar \& Teknik Supervisi Pendidikan dalam rangka pengembangan sumerdaya manusia. Jakarta : Rineka Cipta.

Tama, I. K. (2009). Pengaruh Pelaksanaan Supervisi Akademik Tehadap Penguasaan Kompetetensi Pedagogik Ditinjau dari Etos Kerja Pada Guru SMP Negeri 1 Kuta Utara Tahun 2008/2009. Tesis Pasca SarjanaUniversitas Pendidikan Ganesha Singaraja.

Usman. (2018). Upaya Meningkatkan Kompetensi Guru Binaan Dalam Proses Pembelajaran Melalui Supervisi Akademik Di Kelas Semester Satu Tahun Pelajaran 2017/2018 SD Negeri 39 Mataram. JISIP, 2(1). 